\title{
Adherence and entry of Borrelia burgdorferi in Vero cells
}

\author{
K. E. HECHEMY, W. A. SAMSONOFF, H. L. HARRIS and M. McKeE \\ Wadsworth Center for Laboratories and Research, New York State Department of Health, Albany, NY 12201-0509, \\ USA
}

\begin{abstract}
Summary. Adherence to and entry of the parasite into the host is one of the essential elements of microbial pathogenicity. We investigated the adherence to and entry into primate kidney epithelial (Vero) cells of Borrelia burgdorferi by radiolabelling techniques, immunofluorescence and electronmicroscopy. The attachment to and subsequent entry of both untreated and heat $\left(50^{\circ} \mathrm{C}\right)$-treated $B$. burgdorferi into Vero cells occurred at cell-surface sites associated with aggregated coated pits. In contrast, there was minimal attachment of spirochaetes heated at $60^{\circ} \mathrm{C}$. Radiometric studies showed that, with untreated cells, there was incorporation of both ${ }^{14} \mathrm{C}$-glucose-1-phosphate and ${ }^{14} \mathrm{C}$-thymidine, whereas with the $50^{\circ} \mathrm{C}$-treated spirochaetes only glucose-1-phosphate was incorporated, and with the $60^{\circ} \mathrm{C}$-treated spirochaetes neither radionuclide was incorporated. Spirochaetes heated at $50^{\circ} \mathrm{C}$ or $60^{\circ} \mathrm{C}$ did not grow at $35^{\circ} \mathrm{C}$ in culture medium. These results suggest that the presence of certain metabolic activities of the spirochaete but not viability (ability to grow) are necessary for the attachment process. After entry of untreated $B$. burgdorferi, most of the spirochaetes were either free in the cytoplasm or tightly bound to the host membrane. In contrast, $50^{\circ} \mathrm{C}$-treated spirochaetes remained bound to host membrane in large phagosome-like vesicles.
\end{abstract}

\section{Introduction}

The spirochaete Borrelia burgdorferi, ${ }^{1}$ the Lyme disease agent, is transmitted primarily by ticks of the genus Ixodes. The inflammatory disease is characterised by a wide spectrum of clinical manifestations affecting multiple organ systems. ${ }^{2}$

A fundamental feature of the host-parasite relationship is the underlying mechanism by which pathogenic bacteria colonise living surfaces to initially gain a foothold at the potential site of infection. The entry of pathogenic organisms into host cells to evade the immune system allows persistence of the organism and is a feature of organisms that cause chronic infections. ${ }^{3}$ Pathogenic spirochaetes have been shown to adhere more efficiently than non-pathogenic spirochaetes to host cells. ${ }^{4,5}$ Several reports describe the in vitro adherence of $B$. burgdorferi to various mammalian cells of the immune system, ${ }^{6-8}$ non-immune cell lines, ${ }^{9-11}$ and tick-tissue cell cultures. ${ }^{12}$ Although it has been shown recently that the spirochaete appears to pass through cultured cells within a host-derived membrane, ${ }^{13}$ there is little information about the initial events of the cell-spirochaete interaction.

We have recently established co-cultivation conditions that allow $B$. burgdorferi to grow and attach to mammalian cells lines. ${ }^{10}$ In this study, we report the

Received 9 Jan. 1991; accepted 28 March 1991. early events seen when $B$. burgdorferi spirochaetes interact with and enter Vero cells. We used Vero cells because they are kidney epithelium cells derived from primates and it has been shown that the Lyme spirochaete $^{14}$ and associated antigens ${ }^{15}$ are readily isolated from or detected in renal tissue and urine of infected animals.

\section{Materials and methods}

\section{Growth and treatment of $B$. burgdorferi}

B. burgdorferi strain B31 (ATCC 35210) was used. The infectious nature of this strain was demonstrated by its recovery from blood of 3-day-old Wistar rats $48 \mathrm{~h}$ after inoculation. For the attachment experiments, $B$. burgdorferi was grown in BSK II medium ${ }^{16}$ at $35^{\circ} \mathrm{C}$ for $2-3$ days. The suspension was then centrifuged at $5000 \mathrm{~g}$ and the pellet was washed in BSK II twice by centrifugation. The spirochaetes were resuspended in BSK II to the original suspension volume and divided into three aliquots; one was left untreated and two were heat treated. Minimal conditions for heat inactivation were found to consist of treating the spirochaetal suspension at $50^{\circ} \mathrm{C}$ for $20 \mathrm{~min}$ in a water bath. The spirochaetes were also inactivated by heating at $60^{\circ} \mathrm{C}$ for $1 \mathrm{~h}$. Each spirochaetal suspension was then washed and resuspended in BSK II medium as above. 


\section{Radiolabelling of B. burgdorferi}

(i) For quantitative measurements of B. burgdorferi attachment, the spirochaetes were intrinsically radiolabelled by incubation in BSK II containing ${ }^{14} \mathrm{C}-\mathrm{N}$ acetyl glucosamine $4.17 \mu \mathrm{Ci} / \mathrm{ml}$ (specific activity, $0.36 \mu \mathrm{Ci} / \mu \mathrm{mol}$; ICN Biomedicals, Inc., Costa Mesa, CA, USA) at $35^{\circ} \mathrm{C}$ for 3 days. The labelled spirochaetes were then washed three times in BSK II, resuspended and treated as described above.

(ii) For the metabolic studies, treated and untreated spirochaetes $\left(4 \times 10^{7} / \mathrm{ml}\right)$ were also intrinsically radiolabelled by incubation in BSK II containing ${ }^{14} \mathrm{C}$ thymidine $2.27 \mu \mathrm{Ci} / \mathrm{ml}$ (specific activity $48 \mu \mathrm{Ci} / \mu \mathrm{mol}$ ), or ${ }^{14} \mathrm{C}$-glucose-1-phosphate $2 \cdot 27 \mu \mathrm{Ci} / \mathrm{ml}$ (specific activity, $294 \mu \mathrm{Ci} / \mu \mathrm{mol}$ ). Triplicate samples of $50 \mu \mathrm{l}$ each were removed after 0,6 and $26 \mathrm{~h}$ and pipetted on to $3-$ mm filter-paper disks (Whatman International Ltd, Maidstone). Excess unincorporated radiolabels were removed by washing with trichloroacetic acid (TCA)/ ethanol/ether ${ }^{17}$ and the radioactivity (disintegration/ min, dpm) of the TCA precipitate on the disk was counted in a Beckman LS 250 liquid scintillation system.

\section{Vero cells}

Vero cells (ATCC CCL 81, obtained from the American Type Culture Collection) were propagated in plastic flasks containing antibiotic-free Eagle's Minimal Essential Medium with fetal calf serum 5\% (MEM) at $35^{\circ} \mathrm{C}$ for 2 days. Before the attachment experiments, the MEM was decanted and the Vero cells were washed twice in BSK II. Viability of Vero cells was measured before and after each experiment by trypan blue exclusion.

\section{Immune sera}

Lyophilised spirochaetes (1 mg dry weight), prepared as previously described, ${ }^{20}$ were suspended in aluminium hydroxide adjuvant and injected intramuscularly (i.m.) into rabbits. This was repeated twice at weekly intervals without adjuvant. The rabbits were then given Ketaset (Veterinary Products, Bristol Laboratories, Syracuse, NY) by i.m. injection and bled out by cardiac puncture. The enzyme-linked immunoassay $^{20}$ (ELISA) and micro-immunofluorescence $^{21}$ tests (micro-IF) were performed as described previously. The rabbit immune response to the antigens of $B$. burgdorferi was determined by sodium dodecyl sulphate-polyacrylamide gel electrophoresis (SDS-PAGE) and immunoblotting. ${ }^{10}$

\section{Attachment of B. burgdorferi}

Attachment of $B$. burgdorferi to Vero cells was studied as described previously. ${ }^{10}$ Briefly, $2 \times 10^{8}$ spirochaetes (untreated or heat-treated) were coincubated with Vero cells in BSK II medium at $35^{\circ} \mathrm{C}$. Spirochaete-Vero cell samples were taken after 0,6 , 24 and $44 \mathrm{~h}$. The media were decanted and the flasks were washed twice with BSK II medium to remove non-adherent spirochaetes. Spirochaete-Vero cell combinations on cover slips were processed for immunofluorescent light microscopy or for radiometric quantitation, and those in flasks were processed for transmission electronmicroscopy.

Radiometric quantitative measurements. The spirochaetes were counted by dark field microscopy as described previously. ${ }^{18}$ Briefly, the surface area of the observed microscopic field of a $40 \times$ objective was determined with a counting chamber with a Neubauer ruling. The surface area of the microscopic field was calculated at $9.36 \times 10^{-2} \mathrm{~mm}^{2}$ and the surface area of the cover slips used in the counting of spirochaetes was $484 \mathrm{~mm}^{2}$. A factor was then derived by dividing the area of the cover slip by the area of microscopic field, $484 \mathrm{~mm}^{2} / 9 \cdot 36 \times 10^{-2} \mathrm{~mm}^{2}=5171$. To count unattached spirochaetes, $5 \mu \mathrm{l}$ of diluted growth medium containing spirochaetes (9-16/field) was placed on a microscope slide. A cover slip of known surface area was placed on the 5- $\mu \mathrm{l}$ drop and gently pressed to evenly spread the drop. The spirochaetes present in 20 microscopic fields from several areas were counted and the number of spirochaetes $/ \mu \mathrm{l}$ was then derived from the following formula:

$\frac{\text { Number of spirochaetes in } 20 \text { fields }}{20 \times 5 \mu \mathrm{l}} \times \frac{1}{\text { dilution }} \times 5171$

The total radioactivity of unattached spirochaete suspensions at the various sampling times was also determined. Spirochaete samples were pelleted by centrifugation, resuspended in phosphate-buffered saline (PBS; $\mathrm{pH} 7.2$ ) to their original volume and the radioactivity was measured. The specific radioactivity/spirochaete $(\mathrm{dpm} / \mathrm{spirochaete})$ was then determined for each sample.

To quantitate Vero cells, cells grown on cover slips for 0 and $24 \mathrm{~h}$ were trypsinised ${ }^{10}$ and suspended in PBS. Vero cell suspensions were counted with a haemocytometer. The average cell count per cover slip was $4.40 \times 10^{5}\left(\right.$ SD $\left.1.09 \times 10^{5}\right)$ Vero cells. Cell counts at all sampling times were not significantly different throughout the experiments (Student's $t$ test, ${ }^{19} \mathrm{p}>$ 0.05).

At each sampling time, the radioactivity of each of three cover slips was counted and the radioactivity was averaged. The number of spirochaetes was then derived by dividing the radioactivity by the specific activity (dpm/spirochaete) for each sample. Unless stated otherwise, the radioactive and cell counts of attached spirochaetes are expressed $/ 4.40 \times 10^{5}$ cells.

Immunofluorescent microscopy. The cover slips were edge-blotted to drain excess medium and then washed gently for $15 s$ with PBS and air dried. Cells were fixed to cover slips with acetone for $10 \mathrm{~min}$, air dried, and then incubated with rabbit immune serum to $B$. burgdorferi, diluted $\mathrm{l}$ in 400 , at $37^{\circ} \mathrm{C}$ for $30 \mathrm{~min}$. After washing three times in PBS, cover slips were incubated with FITC-goat anti-rabbit globulins for $30 \mathrm{~min}$ at $37^{\circ} \mathrm{C}$. Cover slips were washed again as above, 


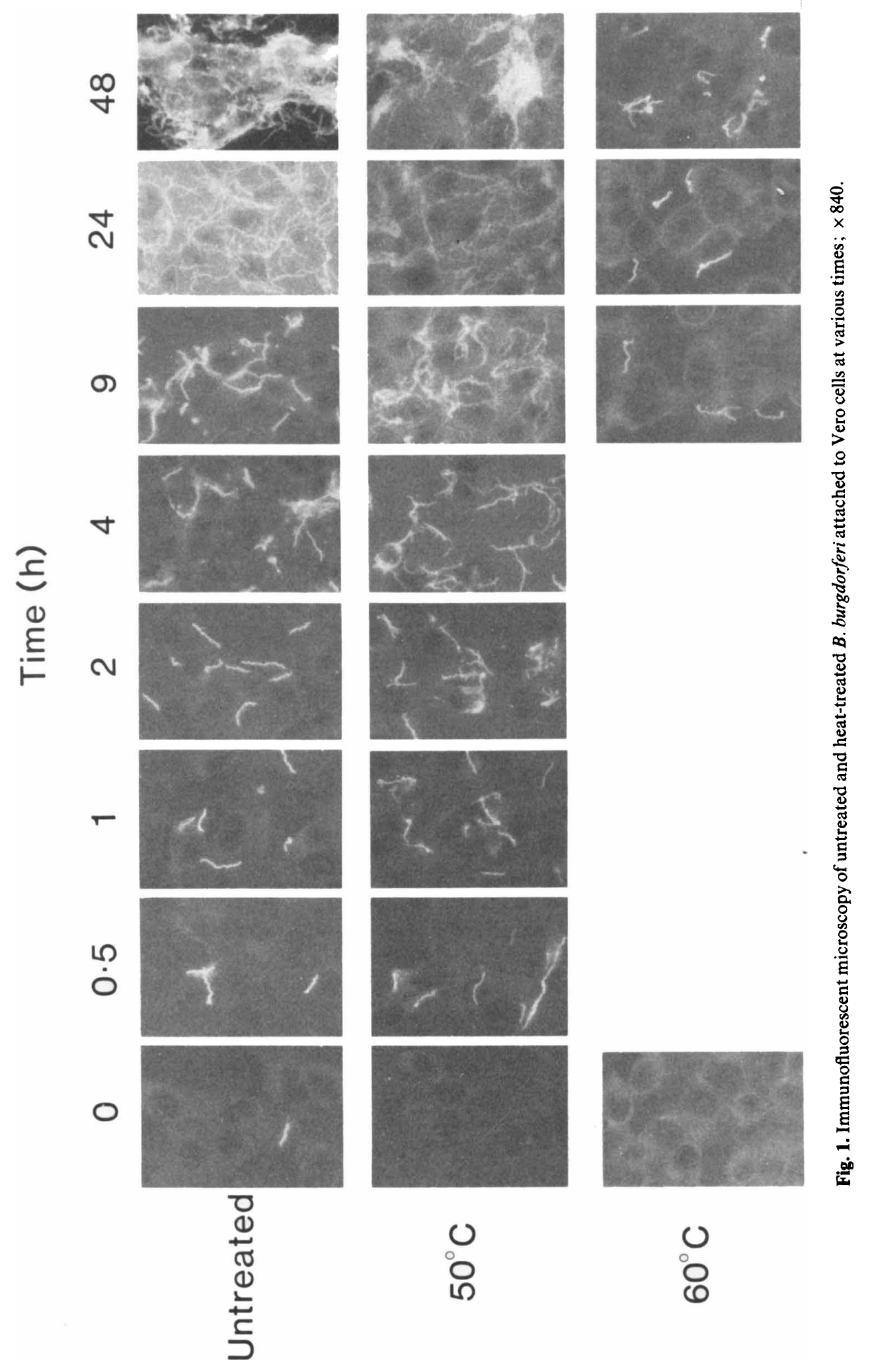


Table. Effect of heat treatments on B. burgdorferi uptake of ${ }^{14} \mathrm{C}$ thymidine and

${ }^{14} \mathrm{C}$ glucose-1-phosphate

\begin{tabular}{lccc} 
& & \multicolumn{2}{c}{ Uptake $\left(\mathrm{DPM}^{*} / 50 \mu \mathrm{l}\right)$} \\
\cline { 3 - 4 } Treatment & $\begin{array}{c}\text { Number of growth } \\
\text { doublings in } 26 \mathrm{~h}\end{array}$ & ${ }^{14} \mathrm{C}$ thymidine & ${ }^{14} \mathrm{C}$ glucose-1-phosphate \\
\cline { 3 - 4 } & & 774 & 256 \\
Untreated & $2 \cdot 5-3$ & 11 & 335 \\
$50^{\circ} \mathrm{C} ; 20 \mathrm{~min}$ & $0 \dagger$ & 0 & 13 \\
$60^{\circ} \mathrm{C} ; 1 \mathrm{~h}$ & $0 \dagger$ & & \\
\hline
\end{tabular}

* Net DPM after subtracting the radioactivity of 0 time. Average counts of triplicate aliquots.

$\uparrow$ No change in total number.

counterstained with Evans blue $1 \%$ for $5 \mathrm{~min}$, washed twice in PBS followed by distilled water, and air dried. The cover slips were mounted in glycerol-PBS on glass slides with the spirochaete-Vero cells side facing down.

Transmission electronmicroscopy. The spirochaeteVero cell monolayers were fixed with formaldehyde $4 \%$ and glutaraldehyde $1 \%$ in phosphate buffer, $\mathrm{pH} 7 \cdot 2$, for $1 \mathrm{~h}$, gently scraped off the plastic flasks, washed in $0.1 \mathrm{M}$ cacodylate buffer, $\mathrm{pH} 7.2$, and post-fixed with osmium tetroxide $1 \%$ in $0.1 \mathrm{M}$ cacodylate. After washing in buffer, the material was centrifuged, encapsulated in agar $2 \%$, dehydrated in a graded ethanol series, and embedded in Epon-Araldite resin. Thin sections were stained with uranyl and lead salts.

To quantitate the number of Vero cells with spirochaetes, $0 \cdot 25-\mu \mathrm{m}$ thick cell sections at each sampling were examined by electronmicroscopy and 200 cell profiles for each were counted. The results

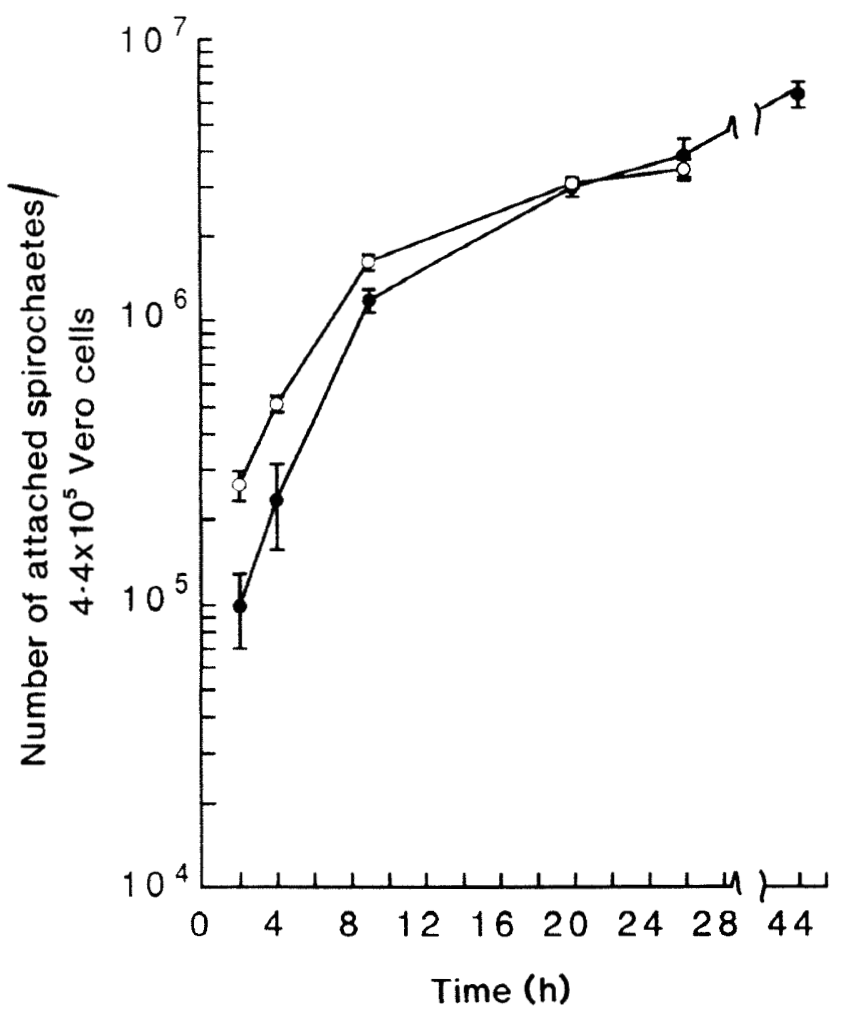

Fig. 2. Radiometric quantitation (mean, ISD) of adherence of spirochaetes to Vero cells: untreated spirochaetes $(O) ; 50^{\circ} \mathrm{C}$-treated spirochaetes $(O)$.

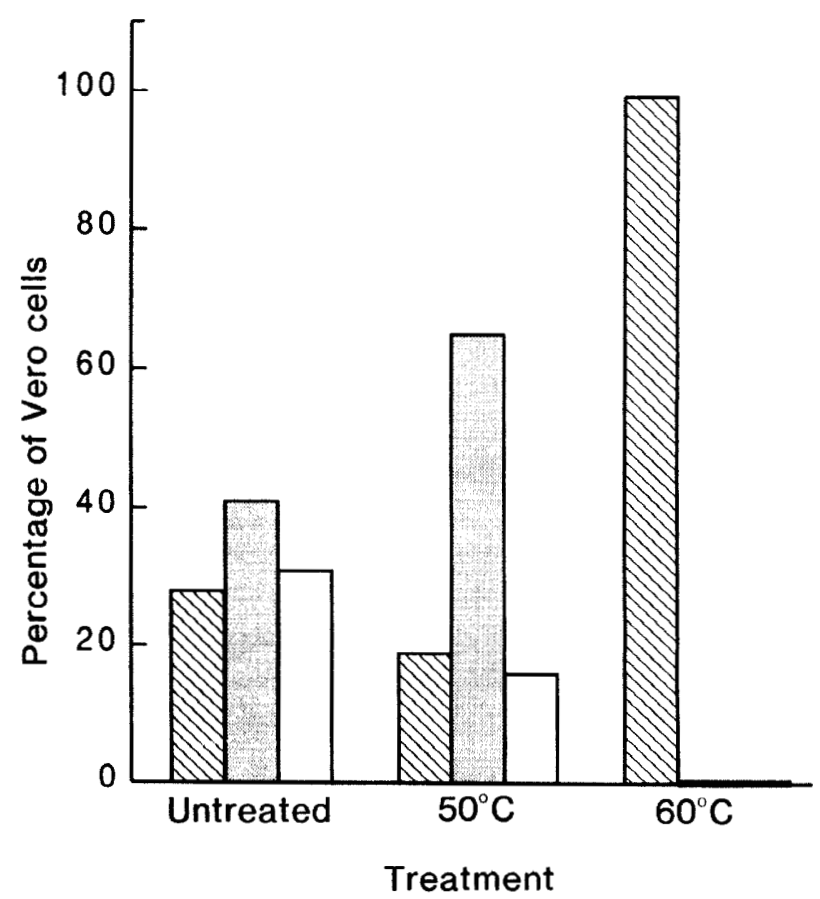

Fig. 3. Percentage of Vero cells $(n=200)$ with (橉) and without ( attached spirochaetes, and with interalised spirochaetes ( $\square$ ) determined by transmission electronmicroscopy. Vero cells with both internalised and attached spirochaetes were scored as internalised.

were scored as follows: no spirochaetes seen (no spirochaetes were seen in association with the Vero cell); spirochaetes attached (if spirochaetes were seen attached to or penetrating the Vero cell); spirochaetes internalised (if a spirochaete was totally within the Vero cell profile, whether or not additional spirochaetes were attached or penetrating the cell surface). We noted also whether or not coated pits and vesicles or their aggregates could be seen at the site of spirochaete attachment or penetration.

\section{Results}

\section{Growth of B. burgdorferi in cell culture}

Examination of the growth of untreated B. burgdorferi in the Vero-cell cultures by dark-field microscopy indicated that the spirochaete had grown well. The generation time of the spirochaete co-cultivated with Vero cells during the log phase $(2-8 \mathrm{~h})$ was $3.87 \mathrm{~h}$. This is in contrast to the generation time of $12 \mathrm{~h}$ when 
B. burgdorferi was cultured in BSK II alone. ${ }^{16}$ Both free and cell-attached spirochaetes were motile. They did not appear to elicit a significant cytopathic effect on Vero cells (only $5 \%$ of the cells were permeable to trypan blue). The monolayer remained intact throughout the $44 \mathrm{~h}$ of co-incubation.

\section{Immune sera}

The ELISA and micro-IF anti-B. burgdorferi titres with the $B$. burgdorferi antigens were 20, 480 and 1024 respectively. The immune response was against a minimum of 31 bands, including flagellar, Osp A, and Osp B antigens.

\section{Heat treatment of $B$. burgdorferi}

The minimum conditions for loss of viability (determined by failure of growth) of $B$. burgdorferi were $50^{\circ} \mathrm{C}$ for $20 \mathrm{~min}$. Loss of viability was assessed by (i) loss of motility when examined by darkfield microscopy; (ii) failure of growth of spirochaetes after incubation in BSK II for $48 \mathrm{~h}$, as indicated by the static optical density; and (iii) the effect on the uptake of radionuclides (table). There was incorporation of radiolabelled thymidine only in the control, untreated spirochaetes, whereas radiolabelled glucose-1-phosphate was incorporated in both untreated and $50^{\circ} \mathrm{C}$ treated spirochaetes, but not in spirochaetes heated at $60^{\circ} \mathrm{C}$ for $1 \mathrm{~h}$.

\section{Attachment of B. burgdorferi}

Immunofluorescence microscopy. Untreated and $50^{\circ} \mathrm{C}$-treated spirochaete suspensions attached to Vero cells (fig. 1) and the degree of specific fluorescence due to spirochaetes attachment increased with the length
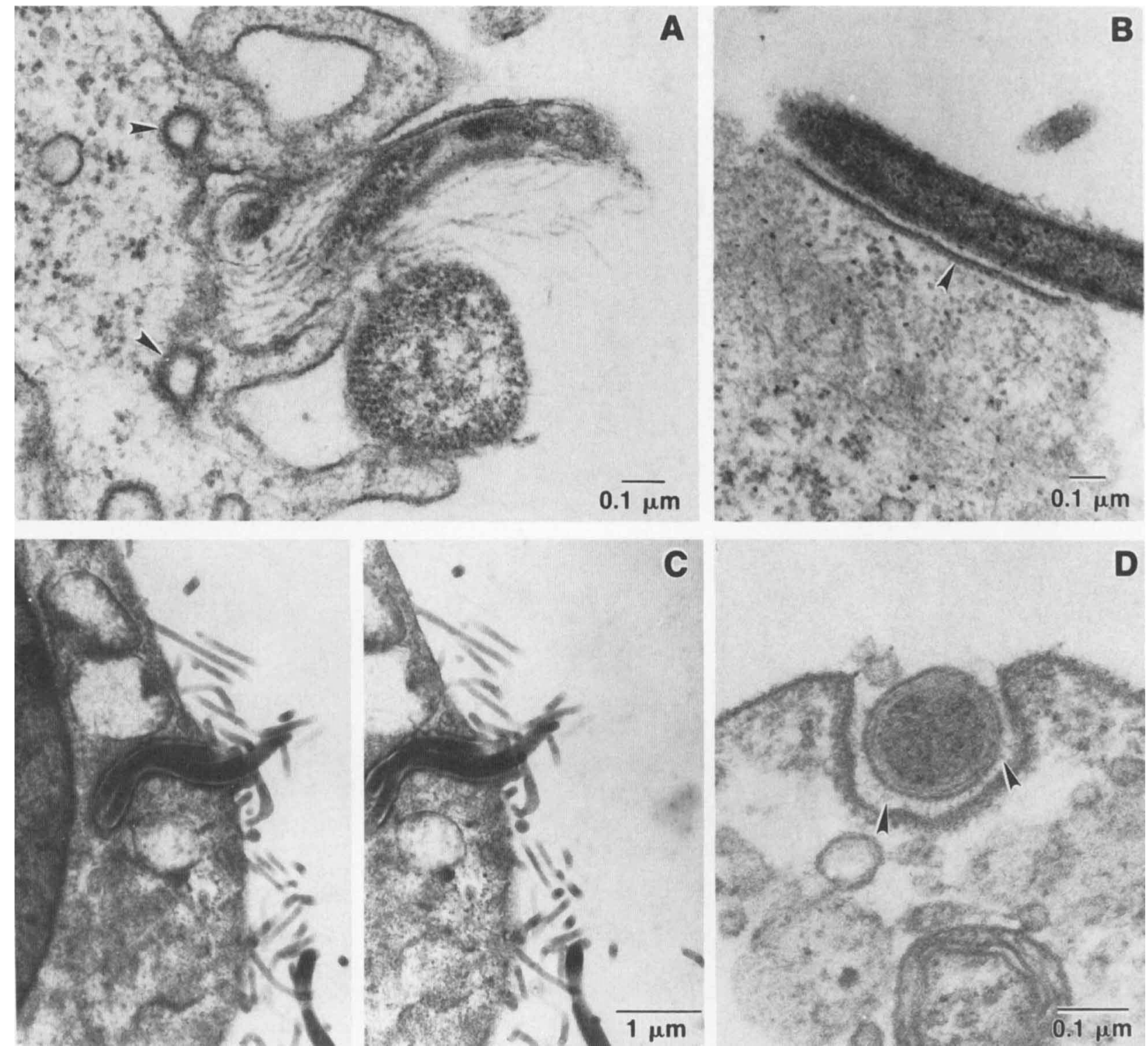

Fig. 4. Attachment of B. burgdorferi to Vero cells. Coated pits and vesicles ( - ) are seen near the attachment site of the spirochaete to the Vero cell (A). Attachment was not limited to the apical tips of the spirochaetes, as spirochaetes were often seen attached laterally to the Vero cell membrane which appeared to be a fusion of several coated pits (B, - ); these structures surrounded the spirochaete (C, stereo pair); electron-dense material between the Lyme spirochaete and the coated-pit regions of the Vero cell was frequently seen (D, - ). 
of incubation. Attachment of $60^{\circ} \mathrm{C}$-treated spirochaetes was minimal.

Quantitative measurements. As a result of growth of untreated radiolabelled spirochaetes during co-incubation with Vero cells, the specific activity decreased with incubation time from $1.93 \times 10^{-4} \mathrm{dpm} / \mathrm{spiro}-$ chaete at $0 \mathrm{~h}$ to $2.63 \times 10^{-5} \mathrm{dpm} /$ spirochaete at $44 \mathrm{~h}$. In contrast, the specific activity in suspensions of the $50^{\circ} \mathrm{C}$-treated spirochaetes remained constant, further indicating that there was no growth. The average specific activity of eight samples of $50^{\circ} \mathrm{C}$-treated spirochaetes was $1.78 \times 10^{-4} \mathrm{dpm} /$ spirochaete (SD $3.8 \times 10^{-5}$ ); the specific activities of the $50^{\circ} \mathrm{C}$-treated spirochaetes at all sampling times were not significantly different from the zero-time sampling ( $p>0.05$, Student's $t$ test). The radiometric measurements of adherence (fig. 2) to the Vero cells of untreated and $50^{\circ} \mathrm{C}$-treated spirochaetes were at background level for the first hour, then increased logarithmically (as indicated by the increase in radioactivity) for the next $8 \mathrm{~h}$. The increase in attachment of the untreated spirochaetes continued but at a lower rate for the duration of the experiment. In contrast, the attachment of the $50^{\circ} \mathrm{C}$-treated spirochaetes appeared to level off after $20 \mathrm{~h}$. The radioactivity counts with $60^{\circ} \mathrm{C}$-treated spirochaetes remained at background level.

Transmission electronmicroscopy. To elucidate the relationship between spirochaetes and Vero cells, all samples were examined by thin $(70 \mathrm{~nm})$ and thick $(250 \mathrm{~nm})$ partial serial sections. In samples taken at $9 \mathrm{~h}$ or earlier, electronmicroscopy results showed few Vero cells with associated spirochaetes $(<1.5 \%$ for all samples). At 24-48 h, in experiments with untreated or $50^{\circ} \mathrm{C}$-treated spirochaetes, most Vero cells had spirochaetes either attached at their surface or
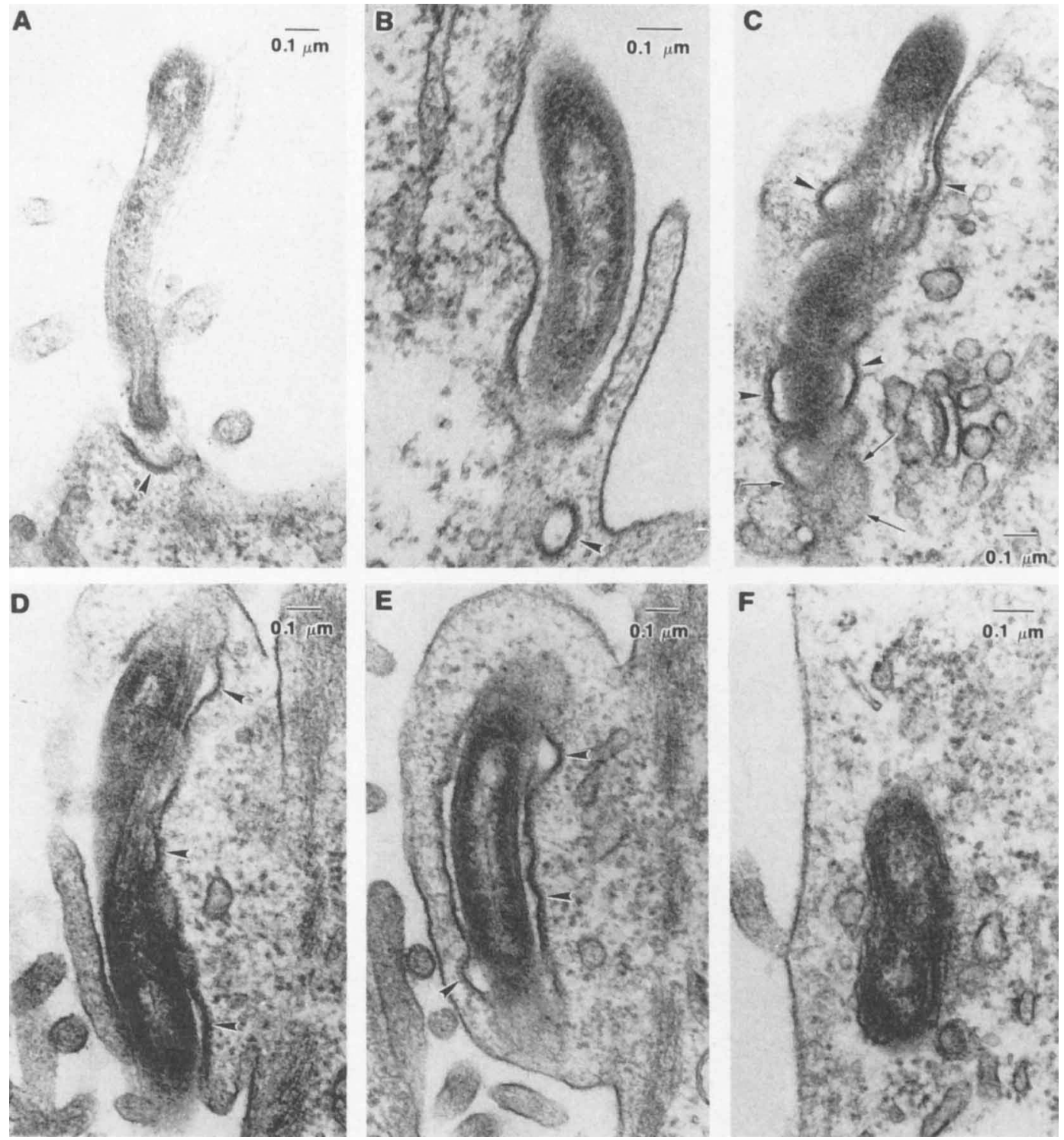

Fig. 5. Engulfment of B. burgdorferi by Vero cells. After attachment at coated pits of the Vero cell (A, - ), the spirochaete is progressively engulfed by the Vero cell membrane, which appeared to consist of several merged coated pits and vesicles (B-E, - ); a tangential section through this region revealed the typical subunit structure associated with clathrin-containing coated vesicles (C, $\rightarrow$ ). Once inside the cell, it was difficult to determine whether the host membrane remained tightly bound to the spirochaete or if the spirochaete was free in the cytoplasm (F). 
internalised ; there was no attachment of $60^{\circ} \mathrm{C}$-treated spirochaetes (fig. 3). Numerous coated pits and vesicles (average diameter 120-150 nm, fig. 4A) and aggregates of these were seen in association with the attached or penetrating spirochaetes $(56 \%$ of profiles seen with Vero cells with untreated spirochaetes, and $70 \%$ of profiles with the $50^{\circ} \mathrm{C}$-treated spirochaetes). The interaction of $B$. burgdorferi at the Vero cell surface was not limited to the apical region of the spirochaete. We often observed long, 800-1000 nm, fused aggregates of coated vesicles along the outer surface of the Vero cell coincident with the lateral bacterial surface (fig. 4B). During engulfment of a spirochaete, the aggregates of coated pits surrounded the bacterium (fig. 4C, the stereo pair) as it entered the cell; in crosssectional views, these aggregates had a diameter of $250-300 \mathrm{~nm}$ and fine fibrous material was seen frequently extending between them and the spirochaete (fig. 4D). This material did not stain with ruthenium red (not shown).

Fig. 5 is a montage of micrographs that illustrate and summarise our ultrastructural observations associated with the penetration of B. burgdorferi into Vero cells. During the initial phases of internalisation, we could clearly observe the host membrane surrounding the spirochaete (fig. 5E), but at later stages, within the cell cytoplasm, it was difficult to ascertain whether the spirochaete was free or tightly bound to the host membrane (figs. 5F, 7A).

Similar results were encountered with $50^{\circ} \mathrm{C}$-treated spirochaetes during the initial attachment and engulfment processes. The spirochaetes were associated with Vero cell coated vesicles (fig. 6A) and the internalisa- tion steps appeared the same (not shown). However, in contrast to the untreated $B$. burgdorferi, the engulfed $50^{\circ} \mathrm{C}$-treated spirochaetes remained surrounded by a sac-like, host-derived membrane structure containing non-electron-dense regions (figs. 6B, 7B).

\section{Discussion}

B. burgdorferi is sensitive to antibiotics in vitro and the disease can be treated successfully during the early stages. However, during the later stages, the disease has proved difficult to treat. The presence of the spirochaete in the host at this stage has not been established. If present, it appears to evade the host immune system. One of several hypotheses proposed is that the spirochoaete may have an intracellular phase where it is protected from antibiotics and from host defence mechanisms. As a preliminary step to test this hypothesis, we have investigated, in an invitro model, the initial interaction between $B$. burgdorferi and the host eukaryotic cell. We have shown previously $^{10}$ that, while the untreated spirochaete adhered to a number of eukaryotic cell lines, it did not adhere preferentially (qualitatively or quantitatively) to any given cell line. In the present investigation, we monitored the adherence of untreated and heat-treated B. burgdorferi to Vero cells.

Receptor-mediated endocytosis (RME), a pathway by which extracellular macromolecules ${ }^{22-27}$ and particles, e.g., viruses, ${ }^{25}$ gain entrance to the intracellular milieu, has recently received much attention. Ligands
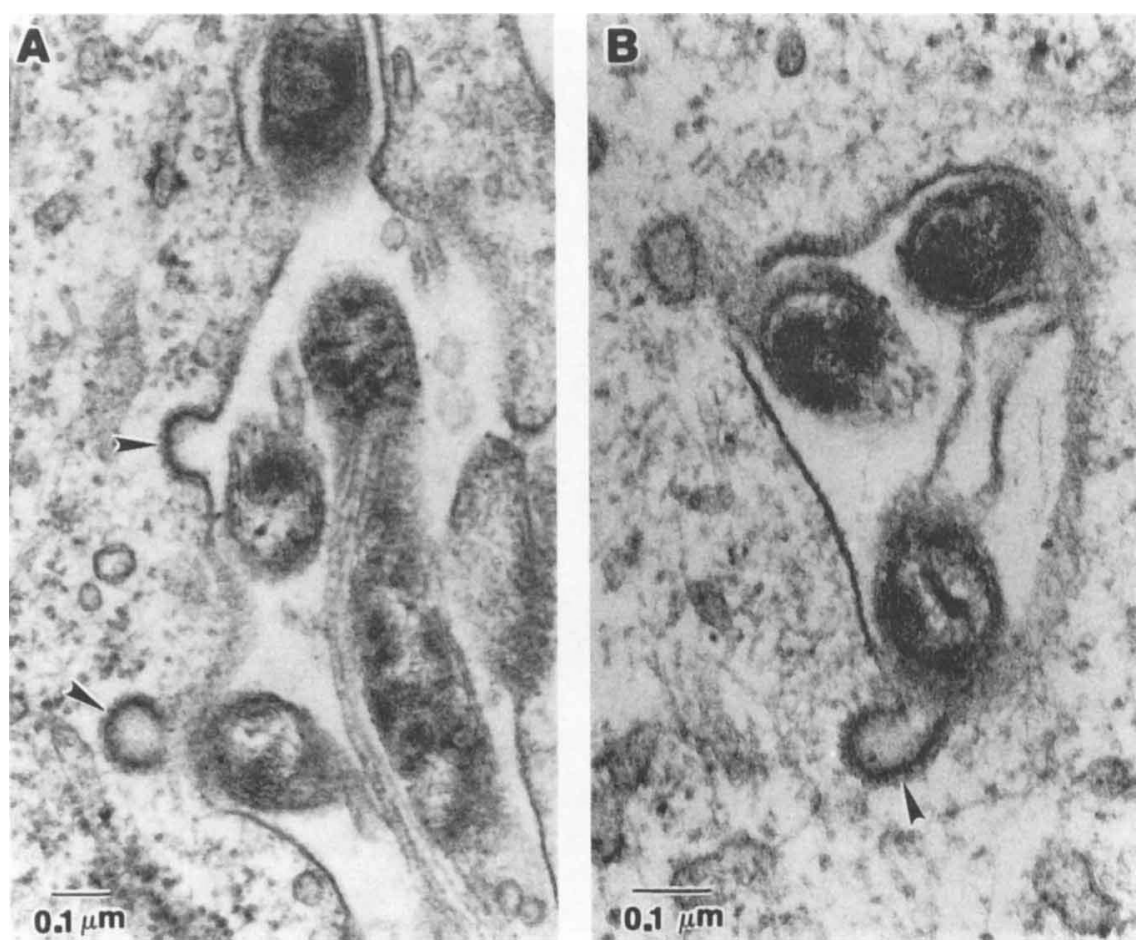

Fig. 6. Attachment of $50^{\circ} \mathrm{C}$-heated B. burgdorferi to Vero cells. Although heat-inactivated, the spirochaete appeared to attach to Vero cells at regions of coated pits and vesicles (A). Internalised $50^{\circ} \mathrm{C}$-treated spirochaetes were loosely surrounded by a distinct host membrane within structures that contained non-electron-dense material (B). 
appear to bind to the receptor cell surface within specialised regions of the plasma membrane ("coated pits") of the eukaryote host cells. ${ }^{27}$ These coated pits are mainly composed of a single protein, clathrin. ${ }^{26}$ Several hypotheses have also been developed to describe mechanisms whereby prokaryotes enter and exit cells. Finlay et al. ${ }^{28}$ used the term "transcytosis", originally described as a form of RME by which macromolecules are transported through cells, ${ }^{29,30}$ to describe how Salmonella choleraesuis, a free-living bacterium with an intracellular phase, passes through a monolayer of kidney cells. However, they did not demonstrate any morphological evidence of coated pits or vesicles. Another hypothesis, "parasitedirected endocytosis", has recently been described by McGee et al. ${ }^{31}$ to characterise the successful invasion of host cells by a number of human pathogens. They suggested that this endocytosis is mediated directly by the organisms or by their products, the latter indicating that organisms need not be viable to enter the host cell. Transmission electronmicroscopy evidence was presented suggesting the participation of clathrin-
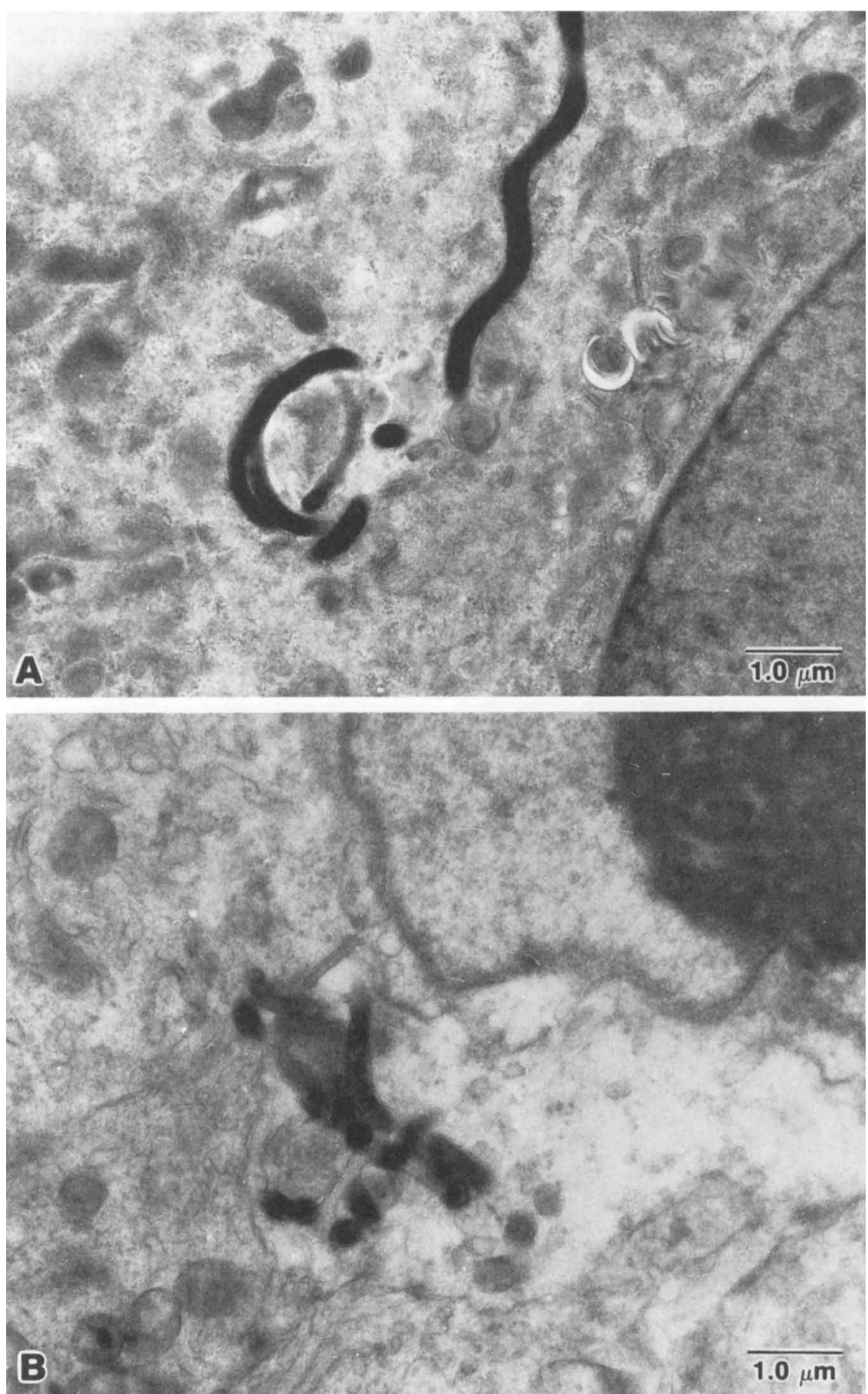

Fig. 7. Thick sections $(250 \mathrm{~nm})$ of untreated (A) and $50^{\circ} \mathrm{C}$-treated (B) B. burgdorferi within Vero cells. It was not possible to determine if the untreated spirochaete was tightly bound by host membrane or was free in the Vero cell cytoplasm. In contrast, $50^{\circ} \mathrm{C}$-treated spirochaetes consistently appeared within host-derived membranes. 
coated membranes during the endocytosis of an obligate intracellular parasite, Chlamydia trachomatis, cultured in McCoy cells. Recently, Clerc and Sansonetti ${ }^{32}$ have shown, by potassium ion depletion studies, evidence for clathrin mobilisation during directed phagocytosis of Shigella flexneri by HEp2 cells; morphological evidence for clathrin coated pits was, however, not presented. ${ }^{32}$ Our transmission electronmicroscopy results show the presence of "clathrin-like" coated pits and vesicles at the attachment of B. burgdorferi on cell-surface sites of the Vero cells. The coated pits were still observed around the spirochaetes soon after their engulfment by the host cells, although they were not observed in the later stages. Presumably, they were recycled to the region of the plasma membrane. ${ }^{27}$

Adherence of $B$. burgdorferi was not limited to the tips of the cells, as we often found specific attachment mediated by what appeared to be clathrin-coated membranes in association with lateral profiles of $\boldsymbol{B}$. burgdorferi cells (fig. 4B). The lateral attachment was similar to results recently reported ${ }^{33}$ for Treponema pallidum, although, in this latter study, no coated pits were observed. This contrasts with previous reports ${ }^{4,5,34}$ on $T$. pallidum adherence, which indicated only polar attachment of this spirochaete to the host cell.

We observed no differences in the early steps of attachment and the endocytic process between untreated or $50^{\circ} \mathrm{C}$-treated spirochaetes presented to Vero cells; however, the $60^{\circ} \mathrm{C}$-treated spirochaetes did not bind. This observation is similar to other bacterial attachment patterns where viability or integrity of the bacteria or integrity of component(s) that mediate attachment is essential. ${ }^{35-37}$ As indicated by our studies, it is possible that the milder, $50^{\circ} \mathrm{C}$ treatment was not harsh enough to destroy the integrity of the spirochaete, or the spirochaetal ligand or metabolic product that initiates binding. We have obtained similar attachment results with ultra violet-treated spirochaetes (data not shown). As with $50^{\circ} \mathrm{C}$ treatment, ultraviolet treatment affected ${ }^{14} \mathrm{C}$ thymidine but not ${ }^{14} \mathrm{C}$ glucose-1-phosphate incorporation into spirochaetes, further indicating the significance of the "integrity of certain metabolic activities" of the organism for adherence and entry.

Preliminary tests indicated that the fate of the enclosed spirochaetes may depend upon their viability. Untreated spirochaetes appeared to be either "enclosed" by a close-fitting host membrane or "free" in the cytoplasm. In contrast, the $50^{\circ} \mathrm{C}$-treated spirochaetes invariably appeared in large vacuoles, filled with non-electron-dense material, that resembled degraded lysosomes.

In summary, B. burgdorferi attached to coated pits on the plasma membrane and then penetrated into the host while enveloped by the host membrane. Biochemical studies are now being undertaken to determine whether the coated pits apparently involved in the adherence process contain clathrin. The fate of the intracellular untreated spirochetes is also being investigated.

\section{References}

1. Burgdorfer W, Barbour AG, Hayes SF, Benach JL, Grunwaldt E, Davis JP. Lyme disease- a tick-borne spirochetosis? Science 1982; 216: 1317-1319.

2. Steere AC, Malawist SE, Bartenhagen NH et al. The clinical spectrum and treatment of Lyme disease. Yale J Biol Med $1984 ; 57: 453-461$.

3. Finlay BB, Falkow S. Common themes in microbial pathogenicity. Microbiol Rev 1989; 53: 210-230.

4. Fitzgerald TJ, Johnson RC, Sykes JA, Miller JN. Interaction of Treponema pallidum (Nichols strain) with cultured mammalian cells: effects of oxygen, reducing agents, serum supplements, and different cell types. Infect Immun 1977; 15: 444-452.

5. Hayes NS, Muse KE, Collier AM, Baseman JB. Parasitism by virulent Treponema pallidum of host cell surfaces. Infect Immun 1977; 17: 174-186.

6. Benach JL, Fleit HB, Habicht GS, Coleman JL, Bosler EM, Lane BP. Interactions of phagocytes with the Lyme disease spirochete : role of the Fc receiptor. J Infect Dis 1984; 150: 497-507.

7. Fumarola D, Cedola MC, Guanti G, Matsuura A, Uede T, Jirillo E. Adherence of Lyme disease spirochetes to rat lymphocytes. Zentralbl Bakteriol Mikrobiol Hyg 1986; 263 : 146-150.

8. Peterson PK, Clawson CC, Lee DA, Garlich DJ, Quie PG, Johnson RC. Human phagocyte interactions with the Lyme disease spirochete. Infect Immun 1984 ; 46: 608-611.

9. Benach JL, Coleman JL, Garcia-Monco JL, Deponte PC. Biological activity of Borrelia burgdorferi antigens. In: Benach JL, Bosler EM (eds) Lyme disease and related disorders. Ann NY Acad Sci 1988; 539: 115-125.

10. Hechemy KE, Samsonoff WA, McKee M, Guttman JM.

Borrelia burgdorferi attachment to mamalian cells. $J$ Infect Dis 1989; 159: 805-806.

11. Thomas DD, Comstock LE. Interaction of Lyme disease spirochetes with cultured eucaryotic cells. Infect Immun 1989; 57: 1324-1326.

12. Kurtti TJ, Munderloh UG, Ahlstrand GG, Johnson RC. Borrelia burgdorferi in tick cell culture: growth and cellular adherence. J Med Entomol 1988; 25: 256-261.

13. Comstock LE, Thomas DD. Penetration of endothelial cell monolayers by Borrelia burgdorferi. Infect Immun 1989; 57 : 1626-1628.

14. Bosler EM, Schultze TL. The prevalence and significance of Borrelia burgdorferi in the urine of feral reservoir hosts. Zentralbl Bakteriol Mikrobiol Hyg A 1986; 263: 40-44.

15. Hyde FW, Johnson RC, White TJ, Shelburne CE. Detection of antigens in urine of mice and humans infected with Borrelia burgdorferi, etiologic agent of Lyme disease. J Clin Microbiol 1989; 27 ; 58-61.

16. Barbour AG. Isolation and cultivation of Lyme disease spirochetes. Yale J Biol Med 1984; 57: 521-525.

17. Mans RJ, Novelli GD. Measurement of the incorporation of radioactive amino acids into protein by a filter-paper disk method. Arch Biochem Biophys 1961; 94: 48-53.

18. Magnuson HJ, Eagle H, Fleischman R. Minimal infectious inoculum of Spirochaeta pallida (Nichols strain) and consideration of its rate of multiplication in vivo. Am J Syph Gonor Ven Dis 1948; 32: 1-18.

19. Taylor RN, Huong AY, Fulford KM, Prezybszewski VA, Hearn TL. Quality controls for immunologic tests. U.S. Department of Health, Education and Welfare. 1979; 79 : 54-83.

20. Hechemy KE, Harris HL, Duerr MJ, Benach JL, Reimer CB. Immunoglobulin $\mathrm{G}$ subclasses specific to Borrelia burgdorferi in patients with Lyme disease. In: Benach JL, Bosler 
EM (eds) Lyme disease and related disorders. Ann $N Y$ Acad of Sci 1988; 539: 162-169.

21. Hechemy KE, Harris HL, Wethers JA et al. Fluoroimmunoassay studies with solubilized antigens from Borrelia burgdorferi. J Clin Microbiol 1989; 27 : 1854-1858.

22. Anderson RGW, Brown MS, Goldstein JL. Role of the coated endocytic vesicle in the uptake of receptor-bound low density lipoprotein in human fibroblasts. Cell 1977; 10: $351-364$.

23. Anderson RGW, Goldstein JL, Brown MS. Localization of low density lipoprotein receptors on plasma membrane of normal human fibroblasts and their absence in cells from a familial hypercholesterolemia homozygote. Proc Natl Acad Sci USA 1976; 73: 2434-2438.

24. Goldstein JL, Brown MS, Anderson RGW, Russell DW, Schneider WJ. Receptor-mediated endocytosis: concepts emerging from the LDL receptor system. Annu Rev Cell Biol $1985 ; 1: 1-39$.

25. Helinius A, Kartenbeck J, Simons K. On the entry of Semliki Forest virus into BHK 21 cells. J Cell Sci 1980; 84: 404 420.

26. Brodsky FM. Living with clathrin: its role in intracellular membrane traffic. Science $1988 ; 242$ : 1396-1402.

27. Pearse BMF. Clathrin and coated vesicles. EMBO J 1987; 6: $2507-2512$.

28. Finlay BB, Gumbiner B, Falkow S. Penetration of Salmonella through a polarized Madin-Darby canine kidney epithelial cell monolayer. J Cell Biol 1988; 107: 221-230.
29. Mostov KE, Simister NE. Transcytosis. Cell 1985; 43: 389390.

30. Simons K, Fuller SD. Cell surface polarity in epithelia. Annu Rev Cell Biol 1985; 1 : 243-288.

31. McGee ZA, Gorby GL, Wyrick PB, Hodinka R, Hoffman LH. Parasite-directed endocytosis. Rev Infect Dis 1988; 10 S311-S316.

32. Clerc PL, Sansonetti PJ. Evidence for clathrin mobilization during directed phagocytosis of Shigella flexneri by HEp2 cells. Microbial Pathogen 1989; 7: 329-336.

33. Konishi H, Yoshii Z, Cox DL. Electron microscopy of Treponema pallidum (Nichols) cultivated in tissue cultures of Sf1Ep cells. Infect Immun 1986; 53: 32-37.

34. Repesh LA, Fitzgerald TJ, Oakes SG, Pozos RS. Scanning electron microscopy of the attachment of Treponema pallidum to nerve cells in vitro. Br J Vener Dis 1982; 58 211-29.

35. Andrade JRC, Da Veiga VF, De Santa Rosa MR, Suassuna I An endocytic process in HEp-2 cells induced by enteropathogenic Escherichia coli. J Med Microbiol 1989; 28: 49 57.

36. Hale TL, Bonventre PF. Shigella infection of Henle intestinal epithelial cells : role of the bacterium. Infect Immun 1979 24: 879-886.

37. Kihlström E, Edebo L. Association of viable and inactivated Salmonella typhimurium 395 MS and MR 10 by HeLa cells. Infect Immun 1976; 14: 851-857. 